\title{
Age-old care and support practices in Southern Africa functioning robustly as sophisticated social technology interventions
}

Liesel Ebersöhn*, Tilda Loots, Ruth Mampane, Funke Omidire, Marlize Malan-van Rooyen

\section{*Correspondence}

University of Pretoria

Liesel Ebersöhn, Centre for the Study of Resilience and Department of Educational Psychology, Faculty of Education, Groenkloof Campus,University ofPretoria, Leyds Street, Groenkloof,Pretoria, 0181 SouthAfrica. Email: liesel.ebersohn@up.ac.za

\begin{abstract}
High-need contexts, such as those in postcolonial Southern Africa, require interventions that provide psychosocial and socioeconomic care and support. This comparative case study uses the lens of indigenous knowledge systems (IKS) to supplement predominantly Western knowledge of care and support interventions. Participatory reflection and action (PRA) were used in 7 conveniently selected Southern African regions reflective of bounded systems with high adversity and likely to portray indigenous belief systems on a regional basis $(n=430$; elders $=240 ;$ youth $=190 ;$ men $=150$ and women $=280$ ). Interactive PRA sessions, focusing on generating narratives about traditional care and support strategies, were recorded and analyzed. It emerged that the IKS care and support interventions still being practised are fundamentally relational and pragmatic pathways of resource management, and include reciprocal donations, shared savings in societies, and partnerships and borrowing/lending. Rather than being outdated vestiges of previous times, these age-old structures continue to function as robust and sophisticated social technologies of care and support.
\end{abstract}

\section{INTRODUCTION AND RATIONALE}

Interventions to buffer people against hardship in emerging-economy contexts are driven mainly from the Western perspectives of outsider funders and often do not achieve the expected outcomes (Battiste, 2005). Like Arnett (2002), we acknowledge that the trade and immigration processes of globalization entail the exchange of information and ideas, and that people in urban areas experience globilization more intensely than those in rural areas. This necessarily affects identify formation because cultures influence one another and consequently become more alike. Acculturation is a plausible consequence of globilization, given that groups of different cultural backgrounds (and their individual members) engage with one another, culminating in cultural and psychological changes (Berry, 2008).

It follows that knowledge systems arguably do not operate in mutually exclusive ways. In fact, the effects of globalization, modernism, individualization, and urbanization in Southern Africa, as elsewhere, make "pure" indigenous traditions and practices inconceivable. Having said this, although globalization has increased radically in recent years, a single homogeneous global culture is not a certainty. Arnett (2002) notes that gaps in technology and lifestyle not only persist but also have grown between affluent and poverty societies, given an urban-rural continuum. There is also evidence that although modernization triggers a series of changes in social structure and knowledge systems, a society's cultural 
heritage continues to influence its current orientation in an individualism-collectivism dimension (Hamamura, 2012).

Intentional investigations that document evidence on how Western and African indigenous knowledge systems compare remain sparse, especially given a global South context. Globilization could therefore lead to a homogenous global society (Arnett, 2002) or promote an extreme differentiation. Like many others, Bhawuk (2008) contends that indigenous research is a model of knowledge generation from cultural insights, which promises to enrich knowledge at a global level. Against this background, the intention of this article is to describe alternative knowledge to supplement mainly Western knowledge about care and support interventions in challenging postcolonial contexts. To this end, care and support findings are presented from emic (Wong, Wong, \& Scott, 2006) and African indigenous knowledge perspectives (Hart, 2010; Aikman, 2010; Odora Hoppers, 2001; Seeland, 2008).

The objective is to describe the ongoing indigenous practices for care and support that the participating youth and elders describe in challenging contexts in South Africa, by answering the question: Which indigenous care and support practices are being used in Southern Africa? The underlying assumption is that interventions may have a greater likelihood of expected outcomes when local, instead of imported, knowledge is integrated conceptually and operationally to take, monitor, and evaluate interventions (Battiste, 2005; OwusuAnsah \& Mji, 2013). Consequently, the descriptive knowledge of this study may be useful when conceptualizing and taking interventions in challenging but mainly African indigenous knowledge contexts. In this way, this article responds to Hamamura's (2012) call for studies on the role of cultural heritage, the emerging patterns of culture and how such patterns continue over time, even in (or in this instance, especially in) the face of a changing environment.

Southern Africa is known for its contexts of high adversity and diversity, typical of postcolonial and emerging-economy countries (Chilisa, 2012; Ebersöhn, 2014; Mearns, Du Toit, \& Mukuka, 2006). These high-risk and high-need Southern African settings have to cope with chronic adversity, rather than one-off stressors. Similarly, Southern African adversity is cumulative and requires individuals, households, neighborhoods, and villages to adapt to a variety of risks at the same time. More than half of the 20 countries ranked lowest in economic competitiveness are in sub-Saharan Africa (Schwab, 2014): South Africa (56th) follows Mauritius (39th) in ranking order and is currently third among the BRICS (Brazil, Russia, India, China and South Africa) economies. Angola $\left(140^{\text {th }}\right)$ is ranked lowest, followed by Mozambique $\left(133^{\text {rd }}\right)$ and Nigeria $\left(127^{\text {th }}\right)$ (Schwab, 2014). The challenge is that Southern Africans live with the daily frustrations of infrastructural limitations due to the inadequate provision of and access to quality health, education, electricity, sanitation, and transport services. Citizens generally distrust politicians and the formal support services provided, which in many cases they see as run by outsiders. Citizens are also vigilant in their concern about security as protection, particularly against violent crime. Southern Africans have to cope with a high incidence of communicable diseases and poor health indicators among themselves, their loved ones, and neighbors. The cumulative effect of these multiple challenges is felt particularly harshly at community level. 
These challenging contexts necessitate care and support interventions which, to be sustained, have to be meaningful to be owned and understood by people in that particular context (Battiste, 2005; Owusu-Ansah \& Mji, 2013). This is especially important because such high-need and high-risk contexts are often the result of the structural disparities of a postcolonial past. Accordingly, instead of grounding interventions in Western ideologies of care, there is a growing realization of the need to move beyond outsider-driven, Eurocentric ideals of support (Battiste, 2005). By contrast, interventions grounded in more culturally and contextually relevant indigenous ways of knowing, problem solving, and support can be embraced (Owusu-Ansah \& Mji, 2013). For this reason, indigenous knowledge has to be deployed in the conceptualization, planning, and implementation of support strategies so that the interventions can achieve the desired levels and be sustainable in a given context.

In South Africa, as in Australia (Edwards \& Taylor, 2008), North America (Chino \& De Bruyn) and Canada (Blackstock \& Trocmé, 2005; Simpson, 2002), most studies focus on providing services to indigenous communities, in contrast to studies asking which indigenous knowledge could inform interventions in challenging contexts with a dominant African indigenous ideology. These studies on service provision therefore often describe how state and institutional services are provided to indigenous communities (Stewart, 2008), for example, mental health (Constantine, Myers, Kindaichi \& Moore, 2004) and child and welfare services (Blackstock \& Trocmé, 2005; Chino \& De Bryun, 2006).

Despite renewed interest in indigenous knowledge systems (IKS), this topic remains underresearched. Some proponents of IKS (Battiste, 2005; McConaghy, 2000) argue that one reason may be that Eurocentric thinkers tend to place a low value on indigenous knowledge because they find IKS to be less systematic than Western science and unsuitable to meet the productivity-focused needs of a Western-driven "modern" world. However, applying Eurocentric knowledge to interventions aimed at addressing challenges in non-Eurocentric contexts has resulted in failure to achieve the envisaged care and support outcomes (Battiste, 2005). By implication, interventions relying solely on Western theories that do not incorporate IKS may misrepresent the challenges in an African indigenous context (Evenden \& Sandstrom, 2011). Such a failure to account for cultural influences has a profound influence on people's experiences of and responses to interventions (Allwood \& Berry, 2006; Macleod, 2004). Little is known about the age-old responses at community level that support the efforts to reduce vulnerability in Southern Africa. The literature on scientific intervention has scant information on IKS in African communities (Mpofu, 2002).

\subsection{IKS}

In general, indigenous refers to phenomena occurring beyond the dominant Western worldview and this term therefore has an African indigenous nature (Hart, 2010). In essence, IKS is an alternative to a dominant Eurocentric worldview. Indigenous is contextspecific but is only considered indigenous if the context is indigenously African (Aikman, 2010) and regarded as an integral part of culture (Odora Hoppers, 2001).

IKS, also called local knowledge, traditional knowledge, rural knowledge, or even indigenous technical knowledge (Mapara, 2009; Warren, 1991), is the body of knowledge of a group of people in the same geographical area. IKS is the knowledge unique to a specific group or 
culture and is usually based on decision making at local level about agriculture, health care, food preparation, education, natural resource management, and a host of other activities in rural communities (Makinde \& Shorunke, 2013; Owusu-Ansah \& Mji, 2013; Warren, 1991). IKS consists of the knowledge and skills that enable people to manage their environment (Sillitoe \& Marzano, 2009). IKS can be viewed as the information base that facilitates communication and decision making, a dynamic concept that is influenced by internal creativity and experimentation (Flavier, Navarro, \& Warren, 1995).

It is important first to understand and respect the cultural context and those involved before attempting to find workable solutions to community problems (Owusu-Ansah \& Mji, 2013). In the emerging global knowledge economy, it is essential for countries to have the ability to build and mobilize knowledge capital so that development can be sustained within the confines of the available physical and financial capital (World Bank, 2014). In this view, the basic component of any country's knowledge system is its indigenous knowledge because people use this knowledge system to apply their skills, experiences, and insights to maintain and improve their livelihood. This article highlights possible IKS technologies for providing care and support to vulnerable people in need.

\subsection{IKS and care and support interventions}

Studies on indigenous ways of care and support are transformative, calling for decolonizing the methodologies of research for indigenous families and communities (Sherwood \& Edwards, 2006; Atalay, 2006; Edwards \& Taylor 2008; Howitt, 1998). Atalay (2006, p. 256) equates decolonization to creating a "counter-discourse to Western approaches that have consistently worked to destroy or silence our indigenous ways of knowing" and which do not sustain care and support. Australian, Canadian, and North American colonial policies on child welfare have weakened the family and community systems of indigenous families by imposing Western culture on them while suppressing, minimizing, and enforcing punitive laws to eradicate indigenous cultural practices and ways of child care and support (Fast \& Collin-Vézina, 2010; Townsend-CrossGnibi, 2004). Accordingly, Ball (2004) hypothesizes that even though "the long era of enforced residential schooling for indigenous children is now over, its negative impacts on self-concept, parenting, social cohesion, and the intergenerational transmission of language and culture remain" (p. 455). It is against this background that the literature on indigenous ways of care and support focuses on redress through affirmation and recognizes the significance of cultural and indigenous ways of knowing, hence the call for decolonization methodologies of indigenous ways of knowing (Atalay, 2006; Edwards \& Taylor 2008; Howitt, 1998).

A comparative study on the childcare practices of three Asian countries (China, Japan, and India) by Yunus (2005) confirms the significance of culture and the shared Confucian goal of harmony in the childcare practices of these three countries. The Confucian goal of harmony is characterized by the principles of "filial piety, ancestral unity and primogeniture and lineage," which might in most cases contrast with Western values (Yunus, 2005, p. 40). The study found that the three Asian countries emphasize the significance of context and contextual messages, and therefore the modelling and demonstrating of behaviour are important in early childhood (Yunus, 2005, p. 40). As a result, the major differences in childcare practices were found to depend on family values, tradition, and religion. 
Indigenous knowledge of care and support often foreground the holistic and relational aspects of care and support toward well-being and has a higher probability of sustainable implementation. Australian scholar Townsend-CrossGnibi (2004) explains as holistic the connected, balanced, and relational ways of living that define Australian Aboriginal people. The holistic view of life is achieved when "ways of knowing, being and doing are approached as holistic ways of life rather than particular behaviours for categorized or segmented concepts and events" (Townsend-CrossGnibi, 2004, p. 2). Townsend-CrossGnibi (2004) centers these holistic approaches of life on the principles of relationship and balance and the values of caring, sharing, and respect.

Across the globe, in another postcolonial setting, Canadian researchers (Richmond, Ross, \& Egeland, 2007; Blackstock \& Trocmé 2005) and Australian researchers (Milroy 2014; Townsend-CrossGnibi, 2004) confirm the significance of Australian Aboriginal holistic approaches as buffers against adversity. Richmond et al. (2007) foreground social support as the care and respect received through social ties. They state that the resulting sense of satisfaction and well-being can buffer against health problems. They posit social support as pivotal to family and community well-being. Blackstock and Trocmé (2005) observe that "emotional, physical, cognitive and spiritual ways of knowing and being guided the resilient development of hundreds of generations of Aboriginal children who were healthy, proud, contributing members of society, living safely at home in their communities" (p. 14). In this case, the culturally based support provided to Aboriginal children and families at risk promoted sustained positive outcomes in child and family well-being.

By contrast, other cultures have a different view of social support and networks. The research conducted in America on how African and Latin American mothers from low socioeconomic backgrounds generate social capital and social networks for social support, reports that social capital can promote or inhibit the upward mobility of the respondents, leading to their viewing some networks as burdensome (Dominguez \& Watkins, 2003). The respondents confirmed that, in most instances, social support networks had the propensity to "inhibit social mobility by enforcing time consuming and professionally limiting expectations on women" (p. 111). This view emphasizes the significance of families' independence in their choice of social networks and how the significance of higher social mobility influences social networks.

From an economic perspective, Katungu (2013) explains how social entrepeneurship has been used as an indigenous response to hardship in Bangladesh, Egypt, and Zimbabwe. Social entrepreneurship refers to the collective development of innovative strategies to address and resolve social problems. The aim is to mobilize resources, using co-operative relationships and partnerships to empower communities to find positive solutions and benefit the lives of community members. In a Lesotho-based study on people living with disability, Sefotho (2013) also found evidence of social entrepeneurship as a traditional response to economic hardship and social exclusion.

Not only does the well-being of African culture rest solely on individual characteristics but also-and what is more important-on socioaffective propositions (Pence \& Nsamenang, 2008). The African philosophy of Ubuntu embodies the holistic principles and values of expressing "compassion, reciprocity, dignity, harmony and humanity in the interests of 
building and maintaining community with justice and mutual caring" (Nussbaum, 2003, p. 2). Concepts of wholeness, community and harmony are entrenched as African cultural values. A sense of the collective means that relationships and interdependence are the basis for collective responsibility (Owusu-Ansah \& Mji, 2013). Malan-van Rooyen (2015) found that reverence for traditional authority and collective connectedness underpinned several coping actions in South African communities living with chronic adversity. In a longitudinal intervention study on teachers in challenging school contexts in South Africa, Ebersöhn (2012) found that teachers used flocking to share scarce resources and mobilize collectively to provide care and support over time to children, teachers in need, and relevant families.

In their review on home-based care in sub-Saharan Africa, Campbell and Foulis (2004) state that including the values relating to social capital, the types of networks and partnerships, were significant to support for carers and their local communities. Similarly, Campbell, Nair, Maimane, and Sibiya (2008) emphasize the important role that indigenous small-scale engagement plays in the care and support of individuals in need. In another interventionfocused study, Kaschula (2008) states that the two main strategies in dealing with the scarcity of food are the use of social capital networks and natural resources. Natural resources are closely linked to social capital networks because these resources are often collected from areas characterized by shared and collective tenure. Social capital networks and systems are vital to the everyday coping of people in need because communities often provide care for the sick, look after children, and donate food (Kaschula, 2008).

\section{METHODOLOGY}

\subsection{Case selection and participants sampled}

In this comparative case study (Cohen, Manion \& Morris, 2007; Creswell, 2009; Thomas, 2011; Willig, 2008; Zartman, 2012), the researchers used participatory reflection and action (PRA; Abedi \& Badregheh, 2011; Chambers, 2006, 2007, 2008, 2012, 2013) to generate data on indigenous ways of responding to people in need. Seven $(n=7)$ municipalities in four Southern African countries were conveniently sampled (Abrams, 2010) as bounded systems characteristic of residents with dominant African indigenous knowledge worldviews (as indicated by an indigenous mother tongue) and high adversity requiring care and support (as indicated by Statistics South Africa, nongovernment care and support interventions, and the partners in the Nelson Mandela Children's Fund 1).

The map in Figure 1 shows the sites sampled inside Southern Africa: Swaziland (rural), Lesotho (rural), Namibia (urban), and South Africa (provinces in Gauteng (urban), Limpopo (peri-urban), Eastern Cape (urban), North West (peri-urban). The sample consequently has a preponderance of South African cases, and it excludes the indigenous knowledge perspectives of residents in nonchallenging settings and those who do not receive care and support interventions. 


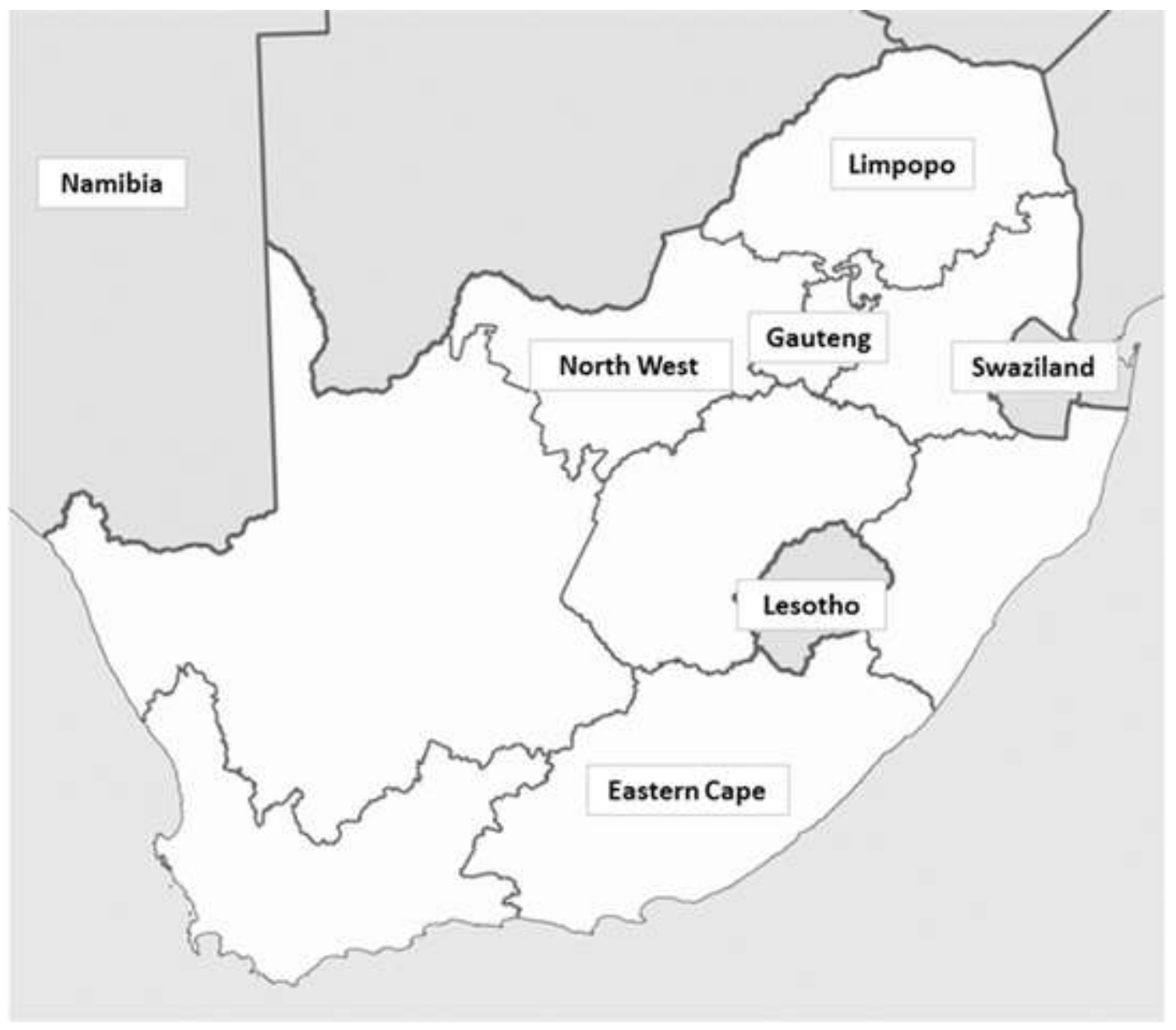

Figure 1. Sampled sites within Southern Africa

The Eastern Cape was formed from the eastern part of the Cape Province as well as from the former Xhosa homelands of Ciskei and Transkei. The population comprises $12.7 \%$ of the total population in South Africa. Black African people form the majority (86.3\%) of the population of the Eastern Cape Province and $77.6 \%$ of the population speaks IsiXhosa as their first language (Statistics South Africa, 2014a). Census 2011 found that the Eastern Cape has the second-lowest average annual household income in South Africa and the highest proportion (58.4\%) of the population between 15 and 64 years of age had not been economically active at the time of Census 2011 (Statistics South Africa, 2014a).

Based on Census 2011, Gauteng has the largest share (23.7\%) of the South African population and $77.4 \%$ of them are in the black African population group (Statistics South Africa, 2014a). The province of Gauteng is the wealthiest province in the Republic of South Africa and also has the highest average annual household income in South Africa (Statistics South Africa, 2014a).

Limpopo is characterized by the indigenous Venda culture (Hammond-Tooke, 2002; Toms, 2005 ) and consists of $10.4 \%$ of the total population in South Africa (Statistics South Africa, 2014a). Most of the sampled Vhembe district consists of $96.7 \%$ black Africans (Statistics South Africa, 2014a) with women- and children-headed households. Although Sepedi is the dominant language spoken in Limpopo, Tshivenda is the main language spoken in the 
sampled Vhembe district (Statistics South Africa, 2014b). Limpopo Province has the lowest average annual household income in South Africa (Statistics South Africa, 2014a) and the highest official unemployment rate of $38.9 \%$ in South Africa (Statistics South Africa, 2014b).

The mainstay of the economy of the North West Province is mining and quarrying, an industry that employs the greater part of the population in this province (Statistics South Africa, 2006). According to Census 2011, this province has $6.8 \%$ of the total population in South Africa, with $89.8 \%$ from the black African population group, and the most widely spoken language is Setswana (Statistics South Africa, 2014a).

Lesotho is an independent country in Southern Africa and is completely surrounded by South Africa. The two official languages of Lesotho are Sesotho and English. According to Lesotho's Demographic Survey in 2011, Lesotho's total population is 1.9 million people . In the urban settings, most people reside in rented houses, though the majority of the people in rural areas have built their own houses. The majority of males reside in their own dwellings. Agriculture is the dominant employment industry for the economically active population in Lesotho, followed by manufacturing and processing (Lesotho Bureau of Statistics, 2014).

Namibia is an independent country in Southern Africa, sharing borders with Zambia, Angola, Botswana and South Africa. According to Census 2011, the total population in Namibia is 2.1 million, and 342,141 people live in the sampled Khomas region. The main languages spoken in this region are Oshiwambo, Afrikaans, Nama/Damara, and Otjiherero. Khomas has one of the highest employment rates (70\%) of all the regions in Namibia and $97 \%$ of people older than 15 years of age are literate (Namibia Statistics Agency, 2011).

Swaziland's population totals 1.2 million and consists mainly of ethnic Swazi. The country's official languages are Siswati and English. It is estimated that about $63 \%$ of the population lives below the poverty line, and approximately $29 \%$ live below the extreme poverty line. Poverty is associated with a high unemployment rate, which is about $28,5 \%$ overall and $52.4 \%$ among the youth. The high HIV/Aids prevalence rate of $31 \%$ is the highest in the world and life expectancy has decreased to approximately 49 years of age (World Bank, 2014).

Both convenience and snowball samplings were used in combination to sample the participants with predominantly African indigenous worldviews, who resided in the selected challenging contexts. The typical challenges confronting the residents across all seven sites include poverty; unemployment; high HIV/Aids prevalence; and limited provision of and access to quality health, education, electricity, sanitation, and transport services. Regional nongovernment intervention coordinators collaborated with the local elders to access the existing social networks and sample participants known to be vulnerable because of poverty-related challenges. These relationships served as leverage for snowball sampling to invite the participation of other acquaintances who were vulnerable and spoke an indigenous language.

Only participants older than 18 years of age were sampled so as to exclude a highvulnerability age group of young children in an already high-vulnerability challenging 
context. With the aim of including age-related indigenous views, the participants in every region could identify themselves as belonging to groups of older women, older men, younger women, or younger men. Table 1 gives an overview of the final number of research participants, stratified by age, gender, and region. It is clear that three challenging contexts are underrepresented among the sampled participants, namely, the North West and Eastern Cape provinces in South Africa and Lesotho in Southern Africa.

Table 1. Overview of the completed sample of participants

\begin{tabular}{|c|c|c|c|c|c|c|c|c|c|}
\hline $\begin{array}{l}\text { Regional } \\
\text { case }\end{array}$ & $\begin{array}{l}\text { Older } \\
\text { men }\end{array}$ & $\begin{array}{c}\text { Older } \\
\text { women }\end{array}$ & $\begin{array}{c}\text { Younger } \\
\text { men }\end{array}$ & $\begin{array}{l}\text { Younger } \\
\text { women }\end{array}$ & $\begin{array}{l}\text { Regional } \\
\text { men }\end{array}$ & $\begin{array}{c}\text { Regional } \\
\text { women }\end{array}$ & $\begin{array}{l}\text { Regional } \\
\text { elders }\end{array}$ & $\begin{array}{c}\text { Regional } \\
\text { youth }\end{array}$ & Total \\
\hline Gauteng & 16 & 37 & 16 & 26 & 32 & 63 & 53 & 42 & 95 \\
\hline Swaziland & 21 & 29 & 19 & 11 & 40 & 40 & 50 & 30 & 80 \\
\hline Limpopo & 16 & 27 & 9 & 31 & 25 & 58 & 43 & 40 & 83 \\
\hline $\begin{array}{l}\text { North } \\
\text { West }\end{array}$ & 5 & 20 & 3 & 8 & 8 & 28 & 25 & 11 & 36 \\
\hline Lesotho & 8 & 6 & 10 & 10 & 18 & 16 & 14 & 20 & 34 \\
\hline $\begin{array}{l}\text { Eastern } \\
\text { Cape }\end{array}$ & 5 & 14 & 8 & 12 & 13 & 26 & 19 & 20 & 39 \\
\hline Namibia & 7 & 29 & 7 & 20 & 14 & 49 & 36 & 27 & 63 \\
\hline Total & 78 & 162 & 72 & 118 & 150 & 280 & 240 & 190 & 430 \\
\hline
\end{tabular}

A demographic questionnaire was developed, based on consultation with a reference team, a content expert, and regional partners and elders. The demographic questionnaire was translated and backtranslated into the regional languages applicable to their use in each region. The demographic questionnaire was administered during the site visits for data collection. In cases in which the participants were illiterate, regional coresearchers read items aloud and wrote down the responses. Out of a total of 430 participants who elected to participate in the study, $91 \%$ completed the questionnaires. The discrepancy in number can be attributed to natural attrition (some participants had to leave early to perform household duties) and some participants elected not to complete the full questionnaire. Nonparametric, descriptive statistics from the demographic questionnaire show stratified (region, age, gender, educational level, language) insights, and patterns.

The majority of the participants (73\%) indicated that they currently resided in the region where they had been born. An overwhelming majority of the participants were older woman (41\%). Just under half of the participants indicated that they were older than 41 years of age, and $15 \%$ fell in the $61-90$ years of age category. Figure 2 shows the distribution of the participants' age groups. 

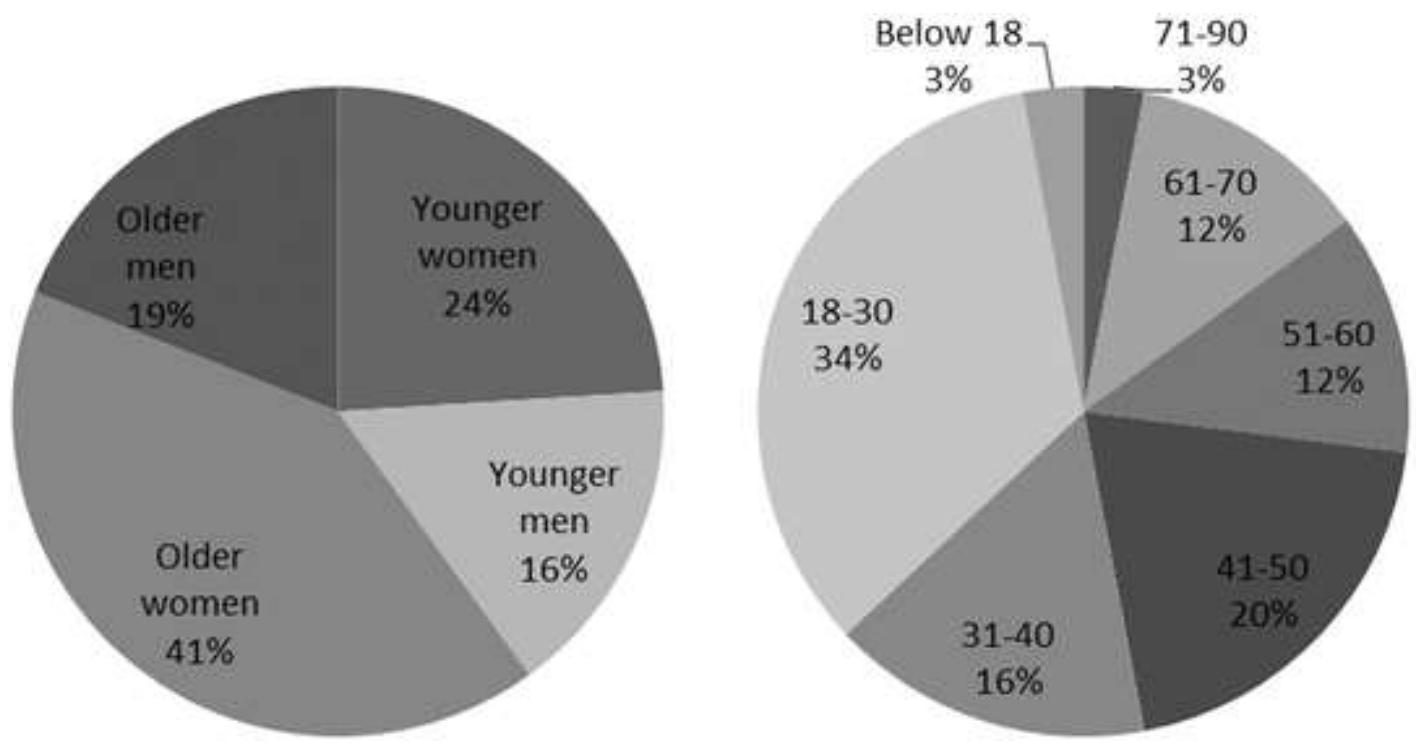

Figure 2. Distribution of age groups of the participants

The educational level of the participants was low because only a few (20\%) had completed primary school or a part of primary school. Some of the other participants $(23 \%)$ had completed a postschool qualification in the form of either a degree or a diploma, as listed in Table 2.

Table 2. Participants' reported highest level of educational qualification

\section{Highest educational qualification}

Grades 7 and lower

Grades 8-9

Grades 10-11

Grade 12

Postschool qualification (diploma)

Postschool qualification (degree)

\section{Percentage}

20

21

20

16

17

6

The participants also indicated which languages they spoke. In most contexts, there were one or two dominant regional languages. In Gauteng, multilingualism and probably a lack of monocultural views were prominent. In all cases, however, English was a parallel dominant language of communication because $40 \%$ of all the participants stated they spoke English, followed by $28 \%$ who stated they spoke siSwati, and a further $20 \%$ who said they spoke isiXhosa.

\subsection{Participatory data generation}

The data generation occurred in the venues that the regional partners and elders had indicated would be appropriate. As stated earlier, the participants divided themselves into groups so that PRA group discussions were facilitated in the same venue, but in the separate groups of older men, older women, younger men, and younger women. Interactive PRA methods were employed to generate narratives of the indigenous care and support given to people in need. 
Questions for PRA activities were developed in consultation with the Nelson Mandela Children's Fund reference team and the content expert, the Era unit partners, the regional partners, and the elders. A researcher posed these questions (in English) to the participants and a regional partner interpreted the questions in the region's dominant language.

Afterwards the groups discussed their answers in a PRA-directed group discussion and their answers were documented using PRA diagramming, by writing down the groups' answers verbatim or by drawing a representative diagram or picture (Abedi \& Badregheh, 2011; Chambers, 2006, 2007, 2008, 2012, 2013). The regional partners cofacilitated one-day PRA sessions of approximately 6 hours per site in the regional language. Each group chose a scribe to document their answers, and after that a chosen presenter conveyed the group's views to the researchers, regional the partner and the rest of the participants. The same process was used in each region. The research team comprised 10 researchers, who were divided into smaller subordinate teams of four to five researchers to attend different research sites. To ensure consistency, all the reserachers attended the first research site in Gauteng, which acted as a pilot study.

The overarching questions used during PRA activities with the participants centered on various forms of indigenous care and support from a systemic perspective. The questions, instructions and aims for the PRA activities used, are listed in Table 3.

Table 3. The questions, instructions, and aims for the PRA activities used

PRA activity

PRA activity 1: Care and support of neighbors/friends in need

PRA activity 2: Care needs of children and the different caregivers involved

PRA activity 3:

Maladaptive traditional practices.

\section{Questions and instructions}

Poster 1: What would you do traditionally when a neghbor or friend is in need? You can refer to songs/folk tales/poems/images that illustrate caring for those in need traditionally.

Poster 2: Write down what children need at which times in their lives to grow up happy. Use green to draw circles aound the things girls need on the same poster. Use blue to draw circles around the things boys need on the same poster.

Poster 3: Who is responsible for providing all the different care needs of children and why does this person play this specific caring role? List all the carers in a child's life in the left-hand column. Write the tasks the carers are responsible for in the middle column. Write the one reason why each carer is responsible for this caring role/task in the right-hand column.

Poster 4: Share examples of traditional care that are bad or not good for people. Discuss examples where traditional care and support are not good for people's happiness and well-being.
Aim

Eliciting IKS knowledge of social support and care.

Eliciting IKS knowledge of views related to children's developmentally appropriate support and care together with role players in children's support and care.

Eliciting IKS on any care and support practices that might not benefit community members and children.

The PRA activities were video-recorded for verbatim transcriptions. The products of PRA activities were photographed as visual data. Observations of the context of interaction (Angrosino \& Mays de Pérez, 2000) during PRA activities were documented in the field notes of multiple researchers and used for triangulating the trends related to the participants' 


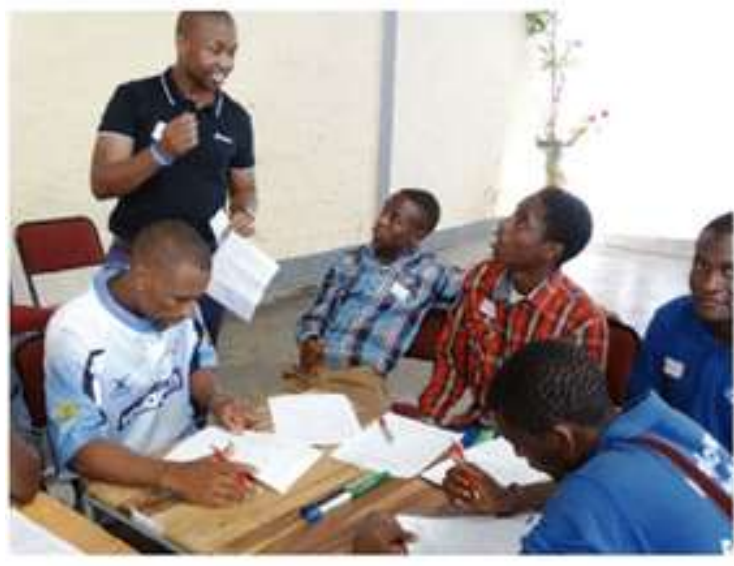

Photograph 1: Explaining the consent form to younger men.

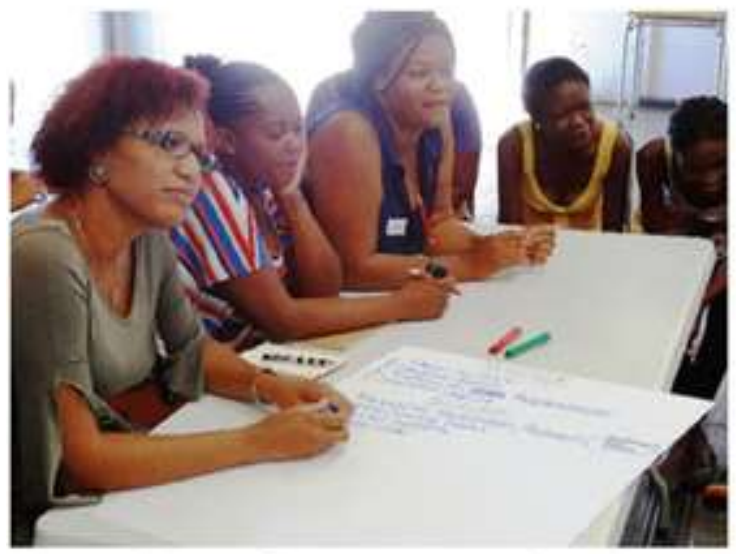

Photograph 3: Group of younger women consulting in their home language to answer a question.

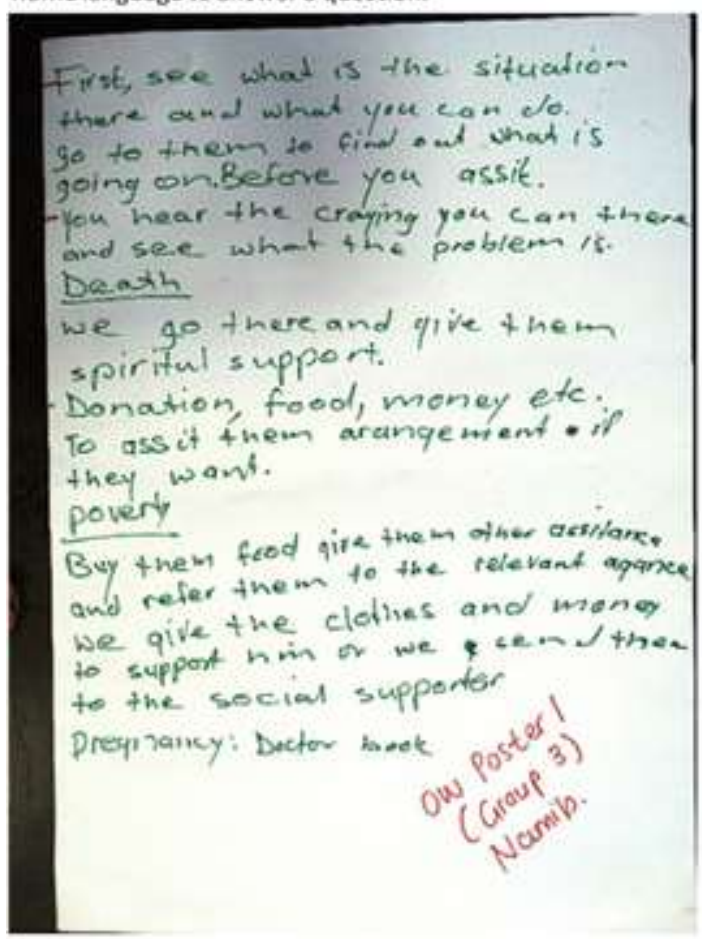

Photograph 5: Answer poster by an older women group.

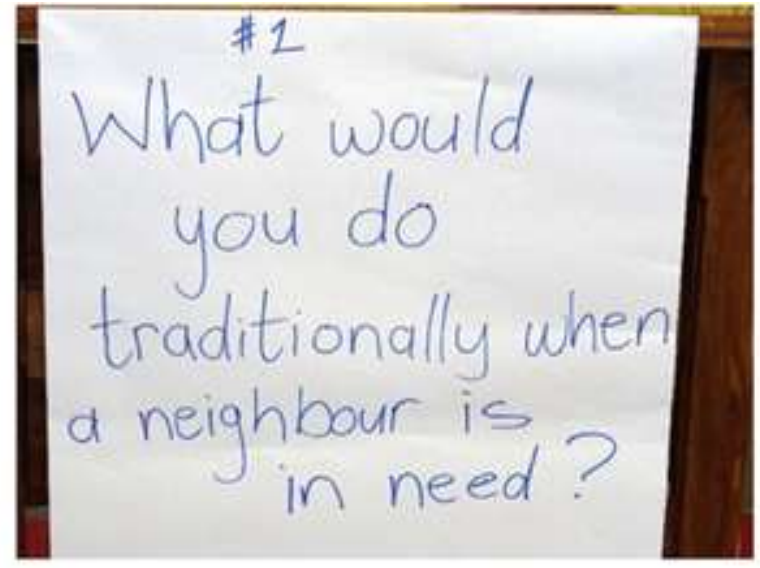

Photograph 2: An example of a question poster shown to groups.

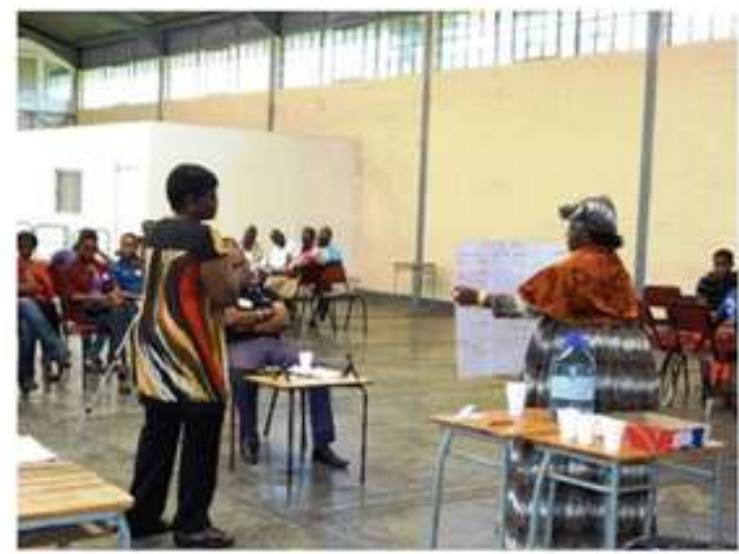

Photograph 4: Older women presenting their answer in their home language to other groups.

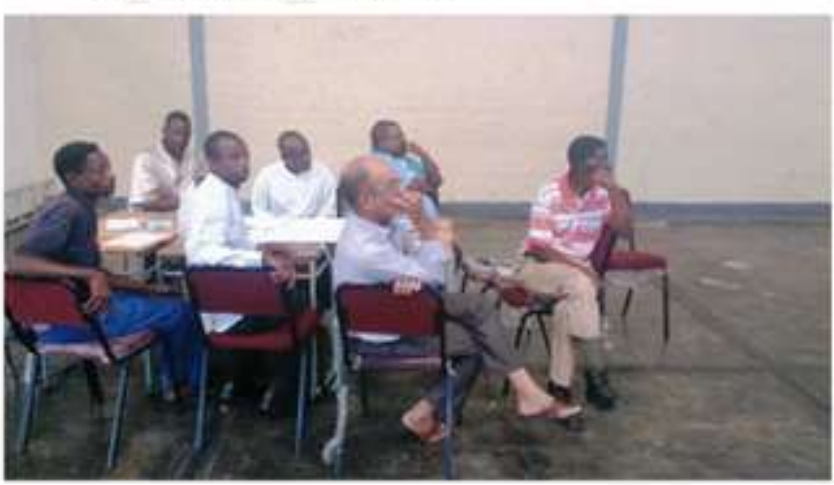

Photograph 6: Older men listening to a group presentation.

Figure 3. Illustration of the PRA data generation stages per site in Namibia 
expressed perspectives. Figure 3 of the data generation in Namibia illustrate the sequence of PRA data-generation stages at each site.

\subsection{In-case and cross-case analysis}

In-case analysis (Yin, 2013) entailed the thematic analysis of data sources (verbatim transcriptions of all PRA group presentations, visual data of answers to PRA posters; Abedi \& Badregheh, 2011; Chambers, 2006, 2007, 2008, 2012, 2013). Then the cross-case analysis (Silverman, 2013) of data sources followed so as to compare the indigenous knowledge about care and support in the regional cases. The in-case and cross-case analysis allowed for understanding, support and care structures in each of the sampled cases and set the stage for making comparisons among the cases. Comparisons lead to richer descriptions of care and support systems which contribute to identifying broader patterns and enable more comprehensive conclusions (Khan \& VanWynsberghe, 2008). A cross-case analysis helped to promote a deeper understanding (Yin, 2013) of the care and support systems in African indigenous knowledge contexts.

The credibility and authenticity of the data were augmented by triangulating across the data sources, researchers, and sites. Rich descriptions of each site and region were provided to enhance the transferability of findings to other similar rural settings. Dependability was enhanced by creating an audit trail of data and using a code-recode strategy during thematic analysis. The confirmability of the findings was strengthened by practising reflexivity during consultation. In addition, knowledge was equitably disseminated in a variety of ways to the various groups of partners.

\subsection{Ethical considerations}

As a central principle of PRA and IKS knowledge generation, the research team comprised members with both scholarly and place-based expertise, which uniquely positioned them to build rapport with the participants and cogenerate trustworthy data. The equality of power for each community partnership was acknowledged for research-related decisions.

Mutuality, meaning that partners felt free to express their expectations and differences, was central to the roles.

A letter of informed consent was translated and the translation checked by means of a backtranslation procedure. The informed consent processes comprised oral engagement with the participants because many were unable to read (see Photograph 1 in figure 3). In cases in which members of the research team were not conversant with a regional language, translators cofacilitated the processes of informed consent. Consequently, the researchers and regional partners explained the purpose of the study to the participants and the nature of their participation-that participation was voluntary and that the participants could withdraw from the study whenever they wished to do so. The participants, as cocreators of knowledge, could opt to consent whether or not they wanted to be identifiable in terms of their names and faces for data and dissemination purposes. Many of the researchers were educational psychologists, which meant that they were able to identify possible distress and, if deemed necessary, could refer participants for counselling in their immediate 
environments, but no adverse effects occurred. In line with the policy at the University of Pretoria, ethical approval was obtained prior to engagement with the participants.

\section{RESULTS}

The following themes of indigenous care and support interventions emerged: reciprocal donations, shared savings in societies and partnerships, and borrowing and lending. These themes are presented and discussed next.

\subsection{Theme 1: Reciprocal donations}

\subsection{1 "Everyone will put in something. Everyone will look where she or he can help."}

This theme refers to the indigenous practice of providing resources to a person in need, without expecting an immediate return. In the long term, however, the expectation is that similar donations would come your way should you be in need. Reciprocal donations therefore entail providing care and support to someone in need through a mutual system of offering resources (goods, services, time, or labor) and expecting, reciprocally, that other resources (goods, services, time, or labor) will be offered to you when you are in need. No money is exchanged as payment for resources. Reciprocal donations seem to be the most prevalent indigenous intervention in challenging contexts.

The rationale for reciprocity is that being vulnerable at some stage in one's life is inevitable. During this vulnerable state, one will need support and care from others. The universality of need is clear in the following excerpts:

Do not laugh at me when I have problems rather help me, because tomorrow it will be you with the very same problem. As my neighbour when I have a problem and you laugh don't expect me to help when you have problems. (North West older women, line 40-44)

In African tradition, whatever happens to your neighbour-death, marriage, sickness even if it's problems with children behaviour-it's also your problem because tomorrow it can also happen to your house. (North West older women, line 119-122).

Poverty and unemployment seemed particularly inescapable to the participants: "When we get to the issue of unemployment, we realised that it affects every one of us not just our neighbour but the entire nation" (North West younger men, line 86-88); "Poverty is curbed by you offering your neighbour support and returns the favour when the time comes" (North West younger men, line 95-96). There are certain limitations on offering help and support, however. Not acting on the principles of reciprocity (and consequently mandated help) is acceptable in instances of noncompliance with cultural values and rules (as evidenced in practices):

That is IF you are a good neighbour. You always make it a point to help them out in such situation. (Swaziland older men, line 6-8)

When the neighbour has nothing, their neighbours come and give their support provided the neighbour is a good person who has no problem or issues with his or her neighbours 
because it is not easy to help someone who is difficult. The neighbour has to be a good person. (Swaziland older women, line 55-60)

Irrespective of age, gender, and region, there was consensus among the participants about the fact that resources (in abundance or scarcity) are shared, contributed, and invested to care for one another and provide support. The participants referred to different forms of reciprocal donations, which included giving material resources; financial donations; bartering; donating labor, attendance, and time as form of assistance; accessing services for individuals and families; and comforting people for psychosocial support. Table 4 below lists these subthemes with some relevant verbatim quotations to illustrate each subtheme.

Table 4. Theme 1 's subthemes and relevant verbatim quotations

\section{Theme 1: Reciprocal donations}

Subtheme 1.1: Material resources

Subtheme 1.2: Financial donations

Subtheme 1.3: Bartering of resources

Subtheme 1.4:

Donating labor, attendance and time

Subtheme 1.5:

Accessing services for individuals and families

Subtheme 1.6: Comforting people for

\section{Verbatim quotations as evidence}

"In case of poverty also, neighbours will also help out with food and clothes. It is not uncommon that when you have something that you don't use anymore, you don't think about throwing it away at first. First think: who can I give it to that may use it again? Who can I give it to? My neighbours might use this food, or this old clothes to wear, and so on." ${ }^{\text {a }}$

"We have financial contribution where if, let's say for example, the mother passed away, what do we do as the neighbours? We usually go to the neighbour's house and we contribute money just for them to buy either food for the funeral or either to buy clothes for the kids. Just some money to help the family out." $b$

"Instead, we had what we call a bartering system. Me offering you my sheep and you giving me the goat. Or someone would have a chicken and the other one would have a rooster."

"During the planting season we help the families to plant and plough using our donkeys to plough so that they can also harvest at the same time with us."d

"At her home we would clean in order to give her some comfort and that the person who lives there may live in a clean environment."

"If the neighbour has no ploughing means, the neighbours come together and make contributions to make it possible for him to plough, plant and have something to eat for his family."

"What we normally do is go over to the family, to wash them or do their house duties that they will not be able to do because they are sick." ${ }^{\mathrm{g}}$

"We take our cleaning material, soaps and quickly clean the house so that when other people come at least the house will be in order. Because when there is a sick person, people lose hope and they are demotivated to do anything. Then you can see that house needs to be swept." ${ }^{\text {h }}$

"We give them our support, collect firewood, ... we help with the cooking as well." $i$ "When he is sick, or one of his family members is sick, here we assist by taking the person or people who are sick to see the doctors, where they will get medical assistance. It might be at the clinics or the hospitals, wherever they will get appropriate help, that important assistance" ${ }^{j}$

"You also give regular visits because it's not only materialistic things that our 
psychosocial support neighbours need. They also need that love and care. ${ }^{\prime k}$

\begin{abstract}
"What we do is that if somebody passed away from a family and have a lot of children, and that family is already poor, the neighbour takes the kids just to support through the period when the funeral is going on so that the kids stay in your neighbour's house and they take care, give love and support and treat the kids as their own."'
\end{abstract}

Note. $\mathrm{NM}=$ North West; $\mathrm{OW}=$ older women; $\mathrm{OM}=$ older men; $\mathrm{YW}=$ younger women; $\mathrm{YM}$ = younger men; $\mathrm{LP}=$ Limpopo; LS = Lesotho; $\mathrm{EC}=$ Eastern Cape; SD = Swaziland.

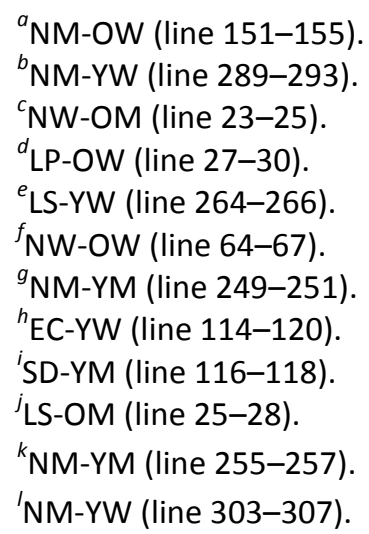

\title{
3.2 Theme 2: Shared savings in societies and partnerships
}

\subsection{1 "Societies that many people can find livelihood from."}

Societies and partnerships as theme refer to the social structures that groups of acquaintances used for shared financial savings as a buffer against hardship. Members deposit small amounts in prescribed and agreed-upon ways. Usually, once annually a member will receive a large payout. Such societies also consult and collectively opt to assist families requiring assistance.

Participants from five regions (Lesotho, Eastern Cape, North West, Limpopo, and Swaziland) referred to societies and partnerships as a mode of support. Participants from the Gauteng region were silent about this subcategory. Although both men and women remarked on the significance of societies and partnerships, older men were silent about this theme.

The older female participants in Limpopo and Lesotho stated: "Normally in communities women club themselves and is commonly known as 'society"' (Limpopo older women, line 55-56); "Then we make a small group as older women and form a society of R5.00s" (Lesotho older women, line 72-73). The older female participants in North West described this practice as follows:

Those meetings where it was discussed ... "Ok, we have this problem-what are we going to do? We don't have the money to buy the coffin. What are we going to do with the children of the deceased?" And every one participated in solving that problem, funeral arrangements. (North West older women, line 131-136) 
Although societies and partnerships are mostly female-managed, broad participation was evident. The older female participants in Namibia explained that it is imperative to collectively donate resources during times of financial strain: "You will look at the financial problems. Everyone will put in something. Everyone will look where she or he can help" (North West older women, line 128-130). The young Basotho male participants explained participation this way:

Another basic thing is that truly (when one is unemployed, my friend or neighbour is unemployed)-here where we live with him/her-there are many societies. Those that many people can find livelihood from. He/she can join that society which collects some contributions and keeps it so that when the year ends, he/she can get some dividends to feed the kids and also the mother and the father in the family (Lesotho younger men, line 200-206).

In the same way, the young male participants in the North West Province described "the hiring of things like vans, tents, cars and other equipment. As neighbours, you can get together and buy some of the equipment like tables by clubbing a certain amount every month so that next time you can be prepared as neighbours" (North West younger men, line 108-111).

\subsection{Theme 3: Borrowing and lending}

\subsection{1 "When the friend or neighbor doesn't have animals, when I have them, we also call them his animals."}

This theme was evident in both genders but in only three of the regional cases (Limpopo, Gauteng, Lesotho), the latter two being urban. Borrowing and lending include the provision of resources on a temporary basis on condition that the specific resource must be returned. As illustrated in the following vignette, the older male participants in Lesotho (Basotho) referred to smart partnerships as a form of lending resources to a person in need:

We now form a smart partnership with such a person. Smart partnership with such a person is to share agriculture. This is crop production. It is known that crops, especially vegetables, we grow in our gardens. Many times when a person is unemployed, he has got time. He has time at his disposal. No matter how poor he might be, there is time on his behalf. That's where we will propose to have that smart partnership of crops, vegetables, and animals. Here we are encouraged by our saying that "unity is strength." And somebody like that, we help even their kids to know how to work with their own hands. So that they work in the gardens and take part in the rearing of animals and so that we help each other. Such animals, when the friend or neighbour doesn't have them, when I have them, we also call them his. That's because we encourage such a person as Basotho. We are known for sharing and lending so that he would have his to be a fortune to him in this way. (Lesotho older men, line 5-20)

The older male participants in Limpopo also referred to lending equipment to people in need: "If I have donkeys, my donkeys will assist my neighbour when he is ploughing. If I have a tractor, it will also assist" (Limpopo older men, line 102-104). The older female 
participants in two regions (Limpopo and Lesotho) and the younger female participants in Lesotho reported that they would lend resources to people in need: "During the planting season, we help the families to plant and plough using our donkeys to plough so that they can also harvest at the same time with us" (Limpopo older women, line 27-30); "We lend our thing" (Lesotho older women, line 136).

Lending and borrowing also occurred for purposes other than those of agriculture: "When there is a funeral we could contribute by ... lend her some equipment" (Lesotho younger women, 269-270). Both the younger female participants in Gauteng and the younger male participants in Limpopo referred to lending money to people in need: "Nowadays if a person is ill, he/she borrows money in order to consult a doctor" (Limpopo younger men, line 1314); "Loan the family money" (Gauteng younger women, line 145-146).

\subsection{Making sense of themes on indigenous care and support practices}

Irrespective of gender, age, or region (urban or rural), the participants in all seven regions reported similar indigenous care and support interventions, which is reflected in the three themes discussed above. It seems that these age-old care and support practices operate strongly as sophisticated social technology interventions across Southern Africa. Reciprocal donations, societies, partnerships, and borrowing and lending all reflect abundant social and cultural capital in challenging contexts in Southern Africa. Instead of being outdated vestiges of previous times, these age-old structures operate as robust and sophisticated social technologies of care and support. Figure 4 illustrates the use of customary practices for current challenges.

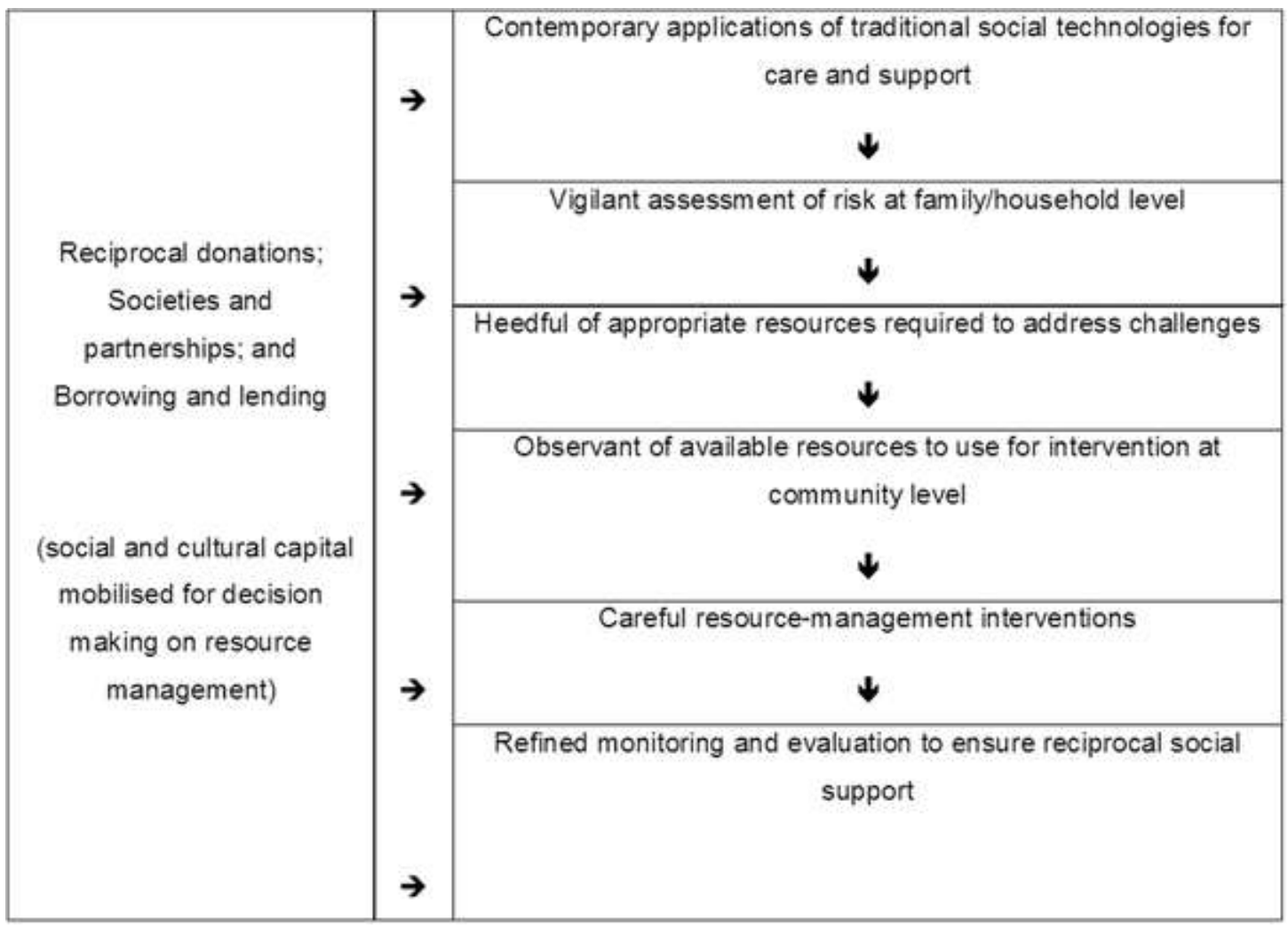

Figure 4. Contemporary applications of traditional social technologies for care and support 
Societies and partnerships emerged as hardy indigenous pathways for care and support interventions. These admirable cultural vestiges work as powerhouses of resource management. The customary structures show adaptability to modern circumstances by continuing to harness the available social and cultural capital, using innovative social technologies. These include vigilant assessment of risk at the family or household level, such as health issues and knowledge of changed needs for earning a livelihood. Risk assessment is accompanied by hands-on knowledge of the appropriate resources that would best address an identified challenge. Insightful planning of an intervention draws on knowledge of the available resources at community level. Acquaintances take careful interventions with a traditional flavor to manage resources intimately within households. These include donations of an array of resources as well as borrowing and lending resources for assistance. Monitoring and evaluation are refined and assume and enforce and normalize the value of reciprocity in resource sharing.

\section{DISCUSSION}

\subsection{Which indigenous care and support practices are being used in Southern Africa?}

We found that indigenous knowledge about care and support used in Southern Africa is fundamentally relational and pragmatic resource management: relational as regards intimate engagement for the use of resources in social networks, and pragmatic about leveraging whatever resources are available for mutual benefit in pathways of social connectedness. Other care and support studies with either relational, pragmatic, or combinations of these include collaborative coping (Revenson \& DeLongis, 2011), instrumental and biological social support (Taylor, 2011), flocking and relationshipresourced resilience (Ebersöhn, 2013), and the conservation of resources (Hobfoll, 2001, 2011).

Each theme that emerged on traditional care and support in Southern Africa can be seen as a social lens for understanding coping, namely, collaborative coping. Collaborative coping refers to shared problem solving (Revenson \& DeLongis, 2011) and active engagement in one another's resources when confronted by adversity (Berg et al., 2008). Reciprocal donating is problem solving in action, with the shared use of resources as central tenet. Odora Hoppers (2002) argues that, by implication, collectivistic African cultures place a high value on an interpersonal dimension of care and support. Similarly, Taylor and Stanton (2007) emphasize the experience of connectedness to others, mutual assistance and obligation as key to care and support at community level.

Like Taylor (2011) we found instances of both instrumental and biological social support. We found that it is customary to provide tangible services to support others to deal with adversity and risk. Explicit and also implicit instrumental support was evident as indigenous pathways of care and support. The finding in our study is that explicit social support, in which people actively draw on existing social networks (Taylor, 2011), underpins the system of societies and partnerships. Giving time and personal engagement for psychosocial support is a prime example of implicit social support, in which people benefit from emotional comfort and reap the benefits of having others in their lives to support them (Taylor, 2011). The intimate personal engagement with others in their homes is one 
example of a biological dimension of social support (Taylor, 2011). This indicates the human inclination to seek attachment and support in times of need and adversity.

As was the case with teachers in several challenging South African school contexts functioning amid adversity (Ebersöhn, 2013), there was evidence of flocking. Flocking implies combining resources to address challenges together. Flocking forms part of relationship-resourced resilience (Ebersöhn, 2012), in which vulnerability is identified collectively, resources are pooled to solve the problems encountered, and existing social networks are used to manage and monitor the care and support systems. Flocking and relationship-resourced resilience are evident in all three themes (societies, reciprocal donations, and borrowing and lending). Examples of flocking include flocking to homes for support (housework, psychosocial care), as well as (especially) women flocking together in societies to provide for future hardship, identify vulnerability, and consult about ways in which available resources could be mobilized for support via the society.

As found in our study, the conservation of resource (COR) theory of stress and coping (Hobfoll, 2001, 2011) is also rooted in the context of chronic adversity. The COR theory suggests that coping arises from a risk or loss of resources. Similar to our findings, COR also stresses communal pathways for coping, such as resource management. The COR communal pathways for managing scarce resources include resource investment, replacement and substitution, and accommodative coping resources. These social innovations for creatively using the available resources for mutual benefit and relief from hardship are also present in Southern African customs of care and support, namely, societies for shared savings, reciprocal donations, and borrowing and lending.

Kuo (2012) also found the COR theory applicable to African indigenous ways of addressing adversity. Kuo (2012) emphasizes that COR views an individual as nested in a family, group, or system. Similar to our findings, Kuo (2012) also found that COR gives preference to a group's well-being over individual needs.

Many other authors have found that social connectedness, social capital networks and systems are vital to the everyday coping of Southern African people in need. Campbell and Foulis (2004) in their review on home-based care in sub-Saharan Africa, stress the importance of social capital as a valuable basis for understanding the types of networks and partnerships most likely to support carers and their local communities. These authors note the significance of offering care and support in a supportive social environment, in which actions are designed in ways that strengthen communities' capacities to respond to risk and adversity (Kaschula, 2008; Campbell \& Foulis, 2004). Similarly, Campbell et al. (2008) emphasize the important role that indigenous small-scale engagement plays in the care and support of individuals in need.

The prominence of support for mobilizing agricultural resources shown in our findings (donations, borrowing, and lending to support livelihood activities) resonate with Kaschula's (2008) finding that the two main strategies in dealing with scarcity of food are the use of natural resources and social capital networks. Therefore, in settings of high deprivation, interventions seem promising that link the use of natural resources with social capital networks in terms of collective tenure. Consistent with donations and gifts as a theme 
identified in our study, the narratives of the participants in the study by Kaschula (2008) show that food donation outweighs any other coping strategy in terms of occurrence, consistency, and cultural acceptability (Kaschula, 2008).

Ndhleve, Musemwa, and Zhou (2012) investigated household food security in a coastal rural community in South Africa and the ways in which these households adapted to food scarcity. In line with the theme in our study of borrowing and lending as a way of supporting people in need, households also reported that they borrowed money from friends or relatives. Identified as a silence in our study, Ndhleve et al. (2012) state that in their study, the most frequent way in which households dealt with food shortages was borrowing food from the nearest shops, as these seemed to be the only institutions willing to extend food credit when a household was stranded. Another mitigation measure used in the study by Ndhleve et al. (2012) was resorting to the environment. Households reported that they accessed food from the environment to be consumed, sold, or exchanged (Ndhleve et al., 2012). Exchanging food for other goods or services is similar to the theme of bartering identified in the present study.

Consistent with our findings regarding support at household level to people in need, Memela and Makhaba (2013) also refer to bathing the sick as part of physical and homebased care. Similarly, confirming our findings, Letseka (2013) refer to repairs to the house, improving the living conditions, building a house, or repairing a room as support at the household level. Campbell and Foulis (2004) also emphasize the important role that homebased care plays in the lives of people living with HIV/Aids. In a case study by Campbell et al. (2008) on the existence and quality of the support systems available to people with Aids and their carers in a South African rural area, they stress that caring for the sick is usually done by informal caregivers, who are mainly family members.

\section{Conclusion}

Given the reality that African indigenous knowledge systems are accorded a lower value and regard than Western counterparts, the contribution of this article is evidence of the emic perspectives of elders and youth in particular Southern African rural and urban settings on the care and support practices they have used and are using among themselves to overcome challenges. We oppose a binary position, in which IKS and Western systems are viewed as functioning in mutually exclusive ways. We conclude that, from a globalization perspective, the evidence of existing Southern African practices for care and support arguably constitute a merging of the Western and African indigenous knowledge systems, which can be tapped into for intervention in primarily African indigenous contexts.

Rather than assuming that dominant Eurocentric discourses would automatically be relevant in an African indigenous dominant context, we intentionally aimed at generating knowledge about dominant African indigenous worldviews. In this way, we could generate evidence of the knowledge systems in play, which knowledge could be useful for scholars and practitioners involved in development and intervention when they formulate strategies to support the development of such communities. Eurocentric It is evident from this study that, in specific dominant African indigenous Southern African contexts, the mechanism of 
care and support which is privileged is akin to Western knowledge of social capital and social connectedness.

The present study indicates that operative IKS care and support interventions are fundamentally relational and pragmatic pathways of resource management. In the case of the Southern African sample, modern support interventions mirror the participants' customary beliefs and are inextricably interwoven with cultural and social capital. The intervention that was taken accesses traditional knowledge and adapts indigenous knowledge to respond to new contextual challenges. We therefore argue that indigenous knowledge about interventions for care and support is contextually relevant and shows resilience because these interventions can adapt temporally.

The results reveal that care and support systems have developed over the generations and emphasize social capital and social connectedness. These systems have been refined and adapted in the course of time to meet current contextual demands. Support interventions are structured around responsive social groupings. There are structures in place to identify and anticipate individual and communal needs, evaluate and disburse the available resources, contribute resources, and link the distribution of resources with expectation and to monitor accountable care and support practices. The specific IKS technologies for care and support identified in this study are consistent with the current literature in this field. We recommend further studies investigate the assumption that interventions may have a better likelihood of sustained care and support when local knowledge is integrated conceptually and operationally to take, monitor, and evaluate these interventions.

There is evidence that abundant social and cultural capital are mobilized for supportive interventions in challenging Southern African contexts. Because of the efforts made across generations, indigenous societies have adopted sophisticated strategies to respond to the need for care and support. In effect, indigenous interventions foresee need, have systems in place to identify need, know where to draw on required resources, use various ways to provide resources (bartering, donations and gifts, borrowing and lending, labor and time, and house-based support), have systems in place to distribute resources, have strategies to connect resource allocation with expectations of activity (not passive receiving), and are able to monitor and manage accountable care and support practices. These interventions are examples of an alternative framework within which indigenous care and support strategies can be directed.

We suggest that research should be conducted to (a) explore the functioning of IKS-driven interventions for care and support in comparable challenging contexts; (b) understand indigenous knowledge in underrepresented urban as well as affluent samples; and (c) to investigate an assumption that interventions may have a better likelihood of providing sustained care and support when local, instead of imported, knowledge is integrated conceptually and operationally to take, monitor, and evaluate interventions.

${ }^{1}$ The Nelson Mandela Children's Fund (NMCF) is a charitable organisation founded by Nelson Mandela, the first democratically elected president of South Africa. The mission of this organisation is to change the way in which society treats its children and youth. The NMCF has many regional partners based throughout Southern Africa, who work in close 
collaboration with the fund to achieve their mission. Regional partners who assisted by providing access to research sites in the reported study include the Red Cross, Lesotho; Save the Children, Swaziland; the Church Alliance for Orphans, Namibia; the Albertina Sisulu Special School, Gauteng; Diaz Primary School, Eastern Cape; Sepanapudi Traditional Authority, Limpopo; and the Emmang Basadi Advocacy and Lobby Organisation, North West Province.

\section{REFERENCES}

Abedi, M., \& Badragheh, A. (2011). Participatory rural appraisal (PRA): New method for rural research. Journal of American Science, 7(4), 363-368.

Abrams, L. S. (2010). Sampling 'hard to reach' populations in qualitative research: The case of incarcerated youth. Qualitative Social Work, 9(4), 536-550.

doi:10.1177/1473325010367821

Aikman, S. (2010). Education and indigenous justice in Africa. International Journal of Educational Development, 31(1), 15-22.

Allwood, C.M., \& Berry, J.W. (2006). Origins and development of indigenous psychologies: An international analysis. International Journal of Psychology, 41(4), 243-268.

doi:10.1080/00207590544000013

Angrosino, M. V., \& Mays de Pérez, K. A. (2000). Rethinking observation. From method to context. In N. K. Denzin, \& Lincoln, Y. S. (Eds.), Handbook of qualitative research (2nd ed., pp. 673-702). Thousand Oaks, CA: SAGE.

Arnett, J. J. (2002). The psychology of globalization. American psychologist, 57(10), 774.

Atalay, S. (2006). Indigenous archaeology as decolonizing practice. The American Indian Quarterly, 30(3), 280-310.

Ball, J. (2004). As if Indigenous knowledge and communities mattered: Transformative education in First Nations communities in Canada. The American Indian Quarterly, 28(3), 454-479.

Battiste, M. (2005). Indigenous knowledge: Foundations for first nations. World Indigenous Nations Higher Education Consortium-WINHEC Journal.

Berg, C. A., Wiebe, D. J., Butner, J., Bloor, L., Bradstreet, C., Upchurch, R., \& Patton, G. (2008). Collaborative coping and daily mood in couples dealing with prostate cancer. Psychology and Aging, 23(3), 505-516.

Retrieved from http://psycnet.apa.org/doi/10.1037/a0012687

Berry, J.W. (2008). Globalisation and acculturation. International Journal of Intercultural Relations, 32(4), 328-336. 
Bhawuk,D. P. S. (2008).Globalization and indigenous cultures: Homogenization or differentiation? International Journal of Intercultural Relations, 32, 305-317. doi:10.1016/j.ijintrel.2008.06.002

Blackstock, C., \& Trocmé, N. (2005). Community-based child welfare for Aboriginal children: Supporting resilience through structural change. Social Policy Journal of New Zealand, 24(12), 12-33.

Campbell, C., \& Foulis, C. (2004. Creating contexts for effective home-based care of people living with HIV/Aids. Curationis, 27(3), 5-14.

Campbell, C., Nair, Y.,Maimane, S., \& Sibiya, Z. (2008). Supporting people with Aids and their carers in rural South Africa: Possibilities and challenges. Health \& Place, 14(3), 507-518.

Chambers, R. (2006). Participatory mapping and geographic information systems: Whose map? Who is empowered and who disempowered? Who gains and who loses? The Electronic Journal of Information Systems in Developing Countries, 25(2), 1-11.

Chambers, R. (2007). 'Participation and poverty'. Development, 50(2), 20-25.

Chambers, R. (2008). Revolutions in developmental inquiry. London: Earthscan.

Chambers, R. (2012). Sharing and co-generating knowledges: Reflections on experiences with PRA and CLTS. Institute of Development Studies (IDS) Bulletin, 43(3), 71-87. doi:10.1111/j.1759-5436.2012.00324.x

Chambers, R. (2013). From rapid to reflective: 25 years of Participatory Learning and Action. In H. Ashley, N. Kenton, \& A. Milligan (Eds.), 66 Participatory learning and action tools for supporting sustainable natural resource management and livelihoods (pp. 12-14). London: The International Institute for Environment and Development.

Chilisa, B. (2012). Indigenous research methodologies. Thousand Oaks, CA: SAGE.

Chino, M., \& De Bruyn, L. (2006). Building true capacity: Indigenous models for indigenous communities. American Journal of Public Health, 96(4), 596-599.

Cohen, L., Manion, L., \& Morrison, K. (2007). Research methods in education (6th ed.). London: Routledge.

Constantine, M. G.,Myers, L. J., Kindaichi, M., \& Moore, J. L. (2004). Exploring indigenous mental health practices: The roles of healers and helpers in promoting well-being in people of color. Counseling and Values, 48(2), 110-125.

Creswell, J. W. (2009). Research design: Qualitative, quantitative and mixed methods approaches (3rd ed.). Thousand Oaks, CA: SAGE. 
Dominguez, S., \&Watkins, C. (2003). Creating networks for survival and mobility: Social capital among African-American and Latin-American low-income mothers. Social problems, 50(1), 111-135.

Ebersöhn, L. (2012). Adding 'flock' to 'fight and flight' as responses to persistent adversity: A honeycomb of resilience where supply of relationships meets demand for support. Journal of Psychology in Africa, 22(1) 29-42

Ebersöhn, L. (2013). Building generative theory from case work: The relationship-resourced resilience model. In M. P. Wissing (Ed.),Well-being research in South Africa (pp. 97-122). New York: Springer.

Ebersöhn, L. (2014). Teacher resilience: Theorizing resilience and poverty. Teachers and Teaching: Theory and Practice, 20(5), 568-594. doi:10.1080/13540602.2014.937960

Edwards, T., \& Taylor, K. (2008). Decolonising cultural awareness. Australian Nursing Journal (July 1993), 15(10), 31-33.

Evenden, M., \& Sandstrom, G. (2011). Calling for scientific revolution in psychology: K. K. Hwang on indigenous psychologies. Social Epistemology: A Journal of Knowledge, Culture and Policy, 25(2), 153-166. doi:10.1080/02691728.2011.552127

Fast, E., \& Collin-Vézina, D. (2010). Historical trauma, race-based trauma and resilience of indigenous peoples: A literature review. First Peoples Child \& Family Review, 5(1), 126-136.

Flavier, J. M., Navarro, C. S., \&Warren, D. M. (1995). The regional program for the promotion of indigenous knowledge in Asia. In D. M. Warren, L. J. Slikkerveer, \& D. Brokensha (Eds.), The cultural dimension of development: Indigenous knowledge systems (pp. 479-487). London: Intermediate Technology Publications.

Hall, K., \& Meintjes, H. (2014). Statistics on children in South Africa. University of Cape Town: Children's Institute.

Hamamura, T. (2012). Are cultures becoming individualistic? A cross-temporal comparison of individualism-collectivism in the United States and Japan. Personality and Social Psychology Review, 16(1), 3-24.

Hammond-Tooke,W. D. (2002). The uniqueness of Nguni mediumistic divination in southern Africa. Africa, 72(02), 277-292. Retrieved from http://www.jstor.org/stable/3556991

Hart, M. A. (2010). Indigenous worldviews, knowledge, and research: The development of an indigenous research paradigm. Journal of Indigenous Voices in Social Work, 1(1), 1-16. Retrieved from http://hdl.handle.net/10125/12527

Hobfoll, S. E. (2001). The influence of culture, community, and the nested-self in the stress process: Advancing conservation of resources theory. Applied Psychology, 50(3), 337-421. doi:10.1111/1464-0597.00062 
Hobfoll, S. E. (2011). Conservation of resources theory: Its implication for stress, health, and resilience. In S. Folkman (Ed.), The Oxford handbook of stress, health, and coping (pp. 127147). New York: Oxford University Press.

Howitt, R. (1998). Recognition, respect and reconciliation: Steps towards decolonisation? Australian Aboriginal Studies, 1998(1), 28.

Kaschula, S. A. (2008).Wild foods and household food security responses to Aids: Evidence from South Africa. Population and Environment, 29(3-5), 162-185. doi:10.1007/s11111-0080068-7

Katungu,W. (2013). The contribution of social entrepreneurship in meeting the needs of orphans in the Mberengwa district, Zimbabwe (Unpublished doctoral dissertation). University of Pretoria, South Africa.

Khan, S., \& Van Wynsberghe, R. (2008). Cultivating the under-mined: Cross-case analysis as knowledge mobilization. Forum: Qualitative Social Research, 9(1), Art. 34.

Kuo, B. C. H. (2012). Collectivism and coping: Current theories, evidence, and measurements of collective coping. International Journal of Psychology.

doi: 10.1080/00207594.2011.640681

Lesotho Bureau of Statistics. (2014). Lesotho demographic survey 2011, Volume III. Maseru: Author.

Letseka, M. (2013). Education for Ubuntu/Botho: Lessons from Basotho indigenous education. Open Journal of Philosophy, 3 (2), 337-344.

Macleod, C. (2004). South African psychology and 'relevance': Continuing challenges. South African Journal of Psychology, 34(4), 613-629. doi:10.1177/008124630403400407

Makinde, O. O., \& Shorunke, O. A. (2013). Exploiting the values of indigenous knowledge in attaining sustainable development in Nigeria: The place of the library. Retrieved from http://digitalcommons.unl.edu/libphilprac/908

Malan van Rooyen, M. (2015). Indigenous pathways to adaptive coping in rural communities (Unpublished doctoral dissertation). University of Pretoria, South Africa.

Mapara, J. (2009). Indigenous knowledge systems in Zimbabwe: Juxtaposing postcolonial theory. The Journal of Pan African Studies, 3(1), 139-155.

McConaghy, C. (2000). Rethinking indigenous education: Culturalism, colonialism, and the politics of knowing. Flaxton, Qld: Post Pressed.

Mearns, M. A., Du Toit, A. S. A., \& Mukuka, G. (2006). Conservation of indigenous knowledge at cultural villages: An exploratory study. Mousaion, 24(1), 23-50. 
Memela,N. C., \&Makhaba, V. L. (2013). Culture as anchor or culture as impediment? The plight of child care workers (CCWs) in dealing with HIV related deaths in a children's home. Indilinga: African Journal of Indigenous Knowledge Systems, 12(1), 80-95.

Milroy, H. (2014). Understanding the lives of Aboriginal children and families. Working together: Aboriginal and Torres Strait Islander mental health and well-being principles and practice ( 2 nd ed.). Canberra, Australia: Commonwealth of Australia.

Mpofu, E. (2002). Psychology in sub-Saharan Africa: Challenges, prospects and promises. International Journal of Psychology, 37(3), 179-186. doi:10.1080/00207590244000061

Namibia Statistics Agency. (2011). Namibia 2011-Population and Housing Census Main Report. Namibia: Namibia Statistics Agency.

Ndhleve, S., Musemwa, L., \& Zhou, L. (2012). Household food security in a coastal rural community of South Africa: Status, causes and coping strategies. Journal of Agricultural Biotechnology and Sustainable Development, 4(5), 68-74. doi:10.5897/JABSD12.040

Nel, P. (2006). Indigenous knowledge systems, local community and community in the making. Indilinga. African Journal of Indigenous Knowledge Systems, 5(2), 99-107.

Nussbaum, B. (2003). African culture and Ubuntu. Perspectives, 17(1), 1-12.

Odora Hoppers, C. A. (2001). Indigenous knowledge systems and academic institutions in South Africa. Perspectives in Education, 19(1), 73-86.

Odora Hoppers, C. A. (2002). Indigenous knowledge systems, sustainable livelihoods and the intellectual property system: A peace action perspective. Journal of Peacebuilding \& Development, 1(1), 106-112. doi:10.1080/15423166.2002.373049356048

Owusu-Ansah, F. E., \& Mji, G. (2013). African indigenous knowledge and research. African Journal of Disability, 2(1). Retrieved from doi.org/10.4102/jod.v2i1.30

Pence, A., \& Nsamenang, A. B. (2008). A case for early childhood development in subSaharan Africa. The Hague: Bernard van Leer Foundation.

Revenson, T. A., \& DeLongis, A. (2011). Couples coping with chronic illness. In S. Folkman (Ed.), the Oxford handbook of stress, health, and coping (pp. 101-123). New York: Oxford University Press.

Richmond, C. A., Ross, N. A., \& Egeland, G. M. (2007). Social support and thriving health: A new approach to understanding the health of indigenous Canadians. American Journal of Public Health, 97(10), 1827-1833.

Schwab, K. (Ed.). (2014). The global competitiveness report 2014-2015. Retrieved from http://www3.weforum.org/docs/WEF_GlobalCompetitivenessReport_2014-15.pdf 
Seeland, K. (2000).What is indigenous knowledge and why does it matter today? In K. Seeland, \& F. Schmithüsen (Eds.), Man in the forest-local knowledge and sustainable management of forests and natural resources in tribal communities in India (pp. 27-39). New Dehli: D. K. Printworld.

Sefotho, M. M. (2013). Narratives of differently abled persons: Informing career guidance policy. Unpublished PhD thesis. Pretoria: University of Pretoria.

Sherwood, J., \& Edwards, T. (2006). Decolonisation: A critical step for improving Aboriginal health. Contemporary Nurse, 22(2), 178-190.

Sillitoe, P., \& Marzano, M. (2009). Future of indigenous knowledge research in development. Futures, 41(1), 13-23.

Silverman, D. (2013). Doing qualitative research (4th ed.). Thousand Oaks, CA: SAGE.

Simpson, L. (2002). Indigenous environmental education for cultural survival. Canadian Journal of Environmental Education, 7(1), 13-25.

Statistics South Africa (2006). Provincial profile 2004: North West / statistics South Africa, Report 00-91-06. Pretoria: Statistics South Africa.

Statistics South Africa. (2014a). Census 2011 municipal report, Eastern Cape, Report 03-0171. Pretoria: Statistics South Africa.

Statistics South Africa. (2014b). Census 2011 provincial profile: Limpopo, Report 03-01-78. Pretoria: Statistics South Africa.

Stewart, S. L. (2008). Promoting indigenous mental health: Cultural perspectives on healing from Native counsellors in Canada. International Journal of Health Promotion and Education, 46(2), 49-56.

Taylor, S. E. (2011). Affiliation and stress. In S. Folkman (Ed.), The Oxford handbook of stress, health, and coping (pp. 86-100).New York: Oxford University Press.

Taylor, S. E. \& Stanton, A. L. (2007).Coping resources, coping processes, and mental health. Annual Review of Clinical Psychology, 3, 377-401.

doi:10.1146/annurev.clinpsy.3.022806.091520

Thomas, G. (2011). A typology for the case study in social science following a review of definition, discourse, and structure. Qualitative Inquiry, 17(6), 511-521.

doi:10.1177/1077800411409884

Toms, R. B. (2005). Indigenous knowledge icons, education and sustainable natural resource management. Indilinga African Journal of Indigenous Knowledge Systems: A Cross-

Pollination and Critique, 4(1), 264.

Retrieved from http://www.nfi.org.za/Ethnobiology/ethno.htm 
Townsend-Cross Gnibi, M. (2004). Transcript: Indigenous Australian perspectives in early childhood education. Australian Journal of Early Childhood, 29(4), 1-6.

Warren, D. M. (1991). Using indigenous knowledge in agricultural development. Washington, DC: The World Bank.

Willig, C. (2008). Introducing qualitative research in psychology (2nd ed.). New York: McGraw-Hill.

Wong, P. T. P., Wong, L. C. J., \& Scott, C. (2006). Beyond stress and coping: The positive psychology of transformation. In P. T. P. Wong, \& L. C. J. Wong (Eds.), Handbook of multicultural perspectives on stress and coping(pp (pp. 1-26). New York: Springer.

World Bank. (1997).Knowledge and skills for the information age: The first meeting of the Mediterranean development forum.

Retrieved from: http://www.worldbank.org/html/fpd/technet/mdf/objectiv.htm

World Bank. (2014). Swaziland.

Retrieved from http://www.worldbank.org/en/country/swaziland/overview

Yin, R. K. (2013). Case study research: Design and methods (5th ed.). Thousand Oaks, CA: SAGE.

Yunus, S. A.M. (2005). Childcare practices in three Asian countries. International Journal of Early Childhood, 37, 39-56.

Zartman, I. W. (2012). Comparative case studies. In D. J. Christie (Ed.), The encyclopaedia of peace psychology (pp. 1-4). doi:10.1002/9780470672532.wbepp043 